\title{
Functional effects of the hadal sea cucumber Elpidia atakama (Echinodermata: Holothuroidea, Elasipodida) reflect small-scale patterns of resource availability
}

\author{
A. J. Jamieson • A. Gebruk · T. Fujii • \\ M. Solan
}

Received: 19 May 2011/Accepted: 27 July 2011/Published online: 7 August 2011

(C) Springer-Verlag 2011

\begin{abstract}
Holothuroidea represent the dominant benthic megafauna in hadal trenches $(\sim 6,000-11,000 \mathrm{~m})$, but little is known about their behaviour and functional role at such depths. Using a time-lapse camera at $8,074 \mathrm{~m}$ in the PeruChile Trench (SE Pacific Ocean), we provide the first in situ observations of locomotory activity for the elasipodid holothurian Elpidia atakama Belyaev in Shirshov Inst Oceanol 92:326-367, (1971). Time-lapse sequences reveal 'run and mill' behaviour whereby bouts of feeding activity are interspersed by periods of locomotion. Over the total observation period ( $20 \mathrm{~h} 25 \mathrm{~min}$ ), we observed a mean ( \pm SD) locomotion speed of $7.0 \pm 5.7 \mathrm{BL} \mathrm{h}^{-1}$, but this increased to $10.9 \pm 7.2 \mathrm{BL} \mathrm{h}^{-1}$ during active relocation and reduced to $4.8 \pm 2.9 \mathrm{BL} \mathrm{h}^{-1}$ during feeding. These observations show E. atakama translocates and processes sediment at rates comparable to shallower species despite extreme hydrostatic pressure and remoteness from surfacederived food.
\end{abstract}

\section{Introduction}

Deposit feeding invertebrates, such as the Holothuroidea, dominate benthic megafaunal communities in the deep sea in

Communicated by S. Uthicke.

A. J. Jamieson $(\bowtie) \cdot$ T. Fujii · M. Solan

Oceanlab, Institute of Biological and Environmental Sciences, University of Aberdeen, Main Street, Newburgh,

Aberdeenshire AB41 6AA, UK

e-mail: a.jamieson@abdn.ac.uk

A. Gebruk

P.P. Shirshov Institute of Oceanology, Russian Academy of Sciences, Nakhimovsky Pr. 36, Moscow 117997, Russia terms of abundance and biomass (Rice et al. 1982; Ohta 1983; Sibuet 1985; Billett 1991). A consistent feature of holothurian communities, irrespective of location, is the marked increase in diversity at abyssal depths $(3,000$ $6,000 \mathrm{~m})$ (Billett 1991) relative to bathyal (1,000-3,000 m) (Hansen 1975) and hadal depths (>6,000 m) (Hansen 1957; Belyaev 1989). Frequently observed mass abundances of holothurians, particularly in trenches associated with high productivity in temperate and sub-Antarctic latitudes, have led some authors to refer to the hadal zone as "the kingdom of Holothuroidea" (sensu Belyaev 1989), a view that has been reinforced by trawl-catch frequencies of $88 \%$ at depths $>6,000 \mathrm{~m}$ (comparable only to Polychaeta) and high levels of dominance (75-98\% in number of all organisms retrieved, $>90 \%$ biomass) at depths $>7,500 \mathrm{~m}$ (Belyaev 1989). Although such high returns tend to be associated with trawls confined to the bottom of the axial part of the trenches, where the greatest quantity of organic matter accumulates (Otosaka and Noriki 2000; Danovaro et al. 2003; De Leo et al. 2010; Jamieson et al. 2010), it follows that the cumulative contribution of the Holothuroidea to deep ocean benthic process and functioning must be considerable (Amaro et al. 2010).

Despite such high levels of abundance, intra- and interspecific competition is thought to be low because individual species of holothurians adopt different feeding strategies, including preferential feeding on nutritionally rich patches (Hauksson 1979; Hudson et al. 2005) and/or subtle differences in mobility or feeding behaviour (Hudson et al. 2005; Godbold et al. 2009) that allow them to utilise different fractions of the same detrital food source (Uthicke and Karez 1999; Miller et al. 2000). It is also known that differences in feeding rates (compare, for example, Hudson et al. 2005; Godbold et al. 2009) alter the gut residence time of a food parcel, leading to more efficient digestion and rates of assimilation (Hiratsuka and 
Uehara 2007). Whilst these physiological and behavioural adaptations influence holothurian activity, much of the ingested material is of low nutritional value (Lopez and Levinton 1987), leading to foraging activity that results in significant levels of surficial bioturbation that has seldom been quantified (Sibuet and Lawrence 1981; Bett and Rice 1993; Uthicke 1999; Roberts et al. 2000; Bett et al. 2001). Indeed, a recent review of invertebrate bioturbation (Teal et al. 2008) indicates a paucity of such data from bathyal or abyssal depths (maximum depth data obtained $=$ $5,654 \mathrm{~m}$, Yang et al. 1986) and a complete absence of information from hadal depths. Hence, it is clear that the ecological consequences of particle redistribution following holothurian foraging and feeding activities are not known despite the importance of this group in deep ocean ecosystems.

In contrast to shallower environments, where species can be caught and returned to the laboratory, carrying out controlled experimental manipulations on hadal specimens is difficult. Direct in situ experimental manipulations are possible using remotely operated vehicles (ROVs), but progress is slow as there is only one vehicle capable of sampling $>6,000 \mathrm{~m}$ (Fletcher et al. 2010). A more practical solution is the use of free-fall baited cameras (Jamieson et al. 2009a, b) which allow time-lapse or continuous video recordings of benthic faunal behaviour. Here, we use such technology to present the first detailed in situ account of the locomotion and feeding behaviour of the holothurian Elpidia atakama (Belyaev 1971) (family Elpidiidae) at 8,074 $\mathrm{m}$ in the Richards Deep area of the Peru-Chile trench. This species has never been seen alive and appears to be endemic to the Peru-Chile trench. We compare locomotion speed and feeding behaviour with abyssal analogues and conclude that the observed patterns of activity are consistent with the view that the behaviour of E. atakama reflects exploitation of patchily distributed resources. We contend that the ability to exploit environmental heterogeneity in this way explains, at least in part, why the holothurians are so abundant and outcompete other deposit feeding species at abyssal and hadal depths.

\section{Materials and methods}

Study site

The Peru-Chile Trench (SE Pacific Ocean) is the longest trench in the world (5,900 km $\times 100 \mathrm{~km}$, Angel 1982) and runs parallel to the west coast of South America from Ecuador to central Chile. The trench lies below the Humboldt Current and the Peruvian upwelling system
(Echevin et al. 2008), a region of high surface productivity (averaging $269 \mathrm{~g} \mathrm{C} \mathrm{m}^{-2}$ year $^{-1}$, Longhurst et al. 1995) with values reported as high as $3,613 \mathrm{~g} \mathrm{C} \mathrm{m}^{-2}$ year $^{-1}$ (Fossing et al. 1995).

\section{Equipment}

We deployed Hadal-lander B (Jamieson et al. 2009b), a free-falling lander equipped with a 5 megapixel digital still camera (OE14-208; Kongsberg Maritime, UK) and a Conductivity, Temperature and Depth (CTD) sensor (SBE19plus V2; SeaBird Electronic Inc. USA), at 8,074 $\mathrm{m}$ in the Richards Deep, Peru-Chile trench $\left(23^{\circ} 22.470^{\prime} \mathrm{S}, 71^{\circ}\right.$ $19.973^{\prime} \mathrm{W}$ ) on the 13 September 2010. The camera was mounted vertically (altitude $1 \mathrm{~m}$ ) providing a visible area of $62 \times 46.5 \mathrm{~cm}\left(0.29 \mathrm{~m}^{-2}\right)$. We attached a bait $(\sim 1 \mathrm{~kg}$ of Tuna, Thunnus sp.) to a 1-cm-diameter scaled bar in the centre of the field of view (FOV) and positioned to intersect the sediment-water interface. Time-lapse images were taken at 60-s intervals. The CTD probe recorded temperature $\left({ }^{\circ} \mathrm{C}\right)$, salinity, and pressure (dbar) every $10 \mathrm{~s}$. Lander recover was achieved by acoustically jettisoning ballast weights to initiate the ascent to the surface. CTD data were averaged, and pressure was converted to depth (m) following Saunders (1981).

Image analysis

Motion paths of E. atakama were tracked using ImageJ $1.42 \mathrm{q}$, a Java-based public domain program developed at the USA National Institutes of Health (available at, http://rsb.info.nih.gov/ij/index.html). Images were calibrated and analysed in chronological order. We used the $X-Y$ coordinates at the base of the central feeding tentacle as a location marker and calculated the distance $(\mathrm{cm})$ an individual travelled per time step to determine the absolute locomotion speed $\left(\mathrm{cm} \mathrm{h}^{-1}\right)$ as follows:

$$
a=\frac{d}{t}=\frac{\sqrt{\left(X_{2}-X_{1}\right)^{2}+\left(Y_{2}-Y_{1}\right)^{2}}}{t}
$$

where $\tilde{a}=$ absolute locomotion speed, $\mathrm{cm} \mathrm{h}^{-1} ; d=$ distance, $\mathrm{cm}$; and $t=$ time interval (here, $60 \mathrm{~s}$ ).

We also explore how differences in time-lapse interval alter ecological interpretation by re-calculating the absolute locomotion speed (and percentage deviation in error relative to the highest resolution of observation) for E. atakama at 1-, 2-, 5-, 10-, 20- and 60-min intervals and place our results within the context of other findings published in the scientific literature.

In order to account for body size, we divided $\tilde{a}$ by body length $(\mathrm{BL}=$ longest axis of specimen) to provide a sizespecific speed $\left(\mathrm{BL} \mathrm{h}^{-1}\right)$. 


\section{Results}

We recorded 1,225 images (20 h $25 \mathrm{~min})$ at a calculated depth of $8,072 \mathrm{~m}(=8,276 \mathrm{dbar})$. At this depth, water temperature was $2.25^{\circ} \mathrm{C}$ and salinity was 34.68 . Sequences included observations of the holothurian, Elpidia atakama, and three species of scavenging gammarid amphipods: Eurythenes gryllus, (Thurston et al. 2002), Hirondellea sp.nov. (Perrone et al. 2002) and an unidentified species. After $20 \mathrm{~h}$, the bait remained present but had been significantly reduced by scavenging amphipods (Fig. 1).

E. atakama was observed (starting at 48 min elapsed time) on three occasions (Period A, 218 images or $3 \mathrm{~h}$ 38 min; Period B, 138 images or 2 h 18 min; and Period C, 219 images or $3 \mathrm{~h} 44 \mathrm{~min}$; total $=9 \mathrm{~h} 40 \mathrm{~min}$; Fig. 1), which were separated by periods of time when the individual moved out of the field of view ( $2 \mathrm{~h} 18 \mathrm{~min}$ and $20 \mathrm{~min}$, respectively). Within these sequences, the number of images in which E. atakama was present varied, ranging from 76 images ( $1 \mathrm{~h} 16 \mathrm{~min})$ in Period $\mathrm{B}, 140$ images ( $2 \mathrm{~h} 20 \mathrm{~min}$ ) in Period A, to 203 images ( $3 \mathrm{~h}$ $23 \mathrm{~min}$ ) in Period C. The individual was not always fully visible within the field of view; hence, only images where the head was clearly visible were used to track holothurian activity. We matched exit to entrance positions between sequences and checked body size measurements $(\sim 5.1 \times$ $2.3 \mathrm{~cm}$ ) and confirmed that all appearances were the same individual.

The distance that E. atakama traversed varied over time, but the rate of movement did not appear to be related to the length of time the individual was observed. Maximal locomotion speed was attained during Period A $(96.5 \mathrm{~cm}$ in $140 \mathrm{~min},=41.36 \mathrm{~cm} \mathrm{~h}^{-1}$ or $8.1 \mathrm{BL} \mathrm{h}^{-1}$ ), with lower rates of movement observed in Periods $\mathrm{B}(37.3 \mathrm{~cm}$ in $76 \mathrm{~min},=29.45 \mathrm{~cm} \mathrm{~h}^{-1}$ or $\left.5.8 \mathrm{BL} \mathrm{h}^{-1}\right)$ and $\mathrm{C}(133 \mathrm{~cm}$ in $203 \mathrm{~m},=33.6 \mathrm{~cm} \mathrm{~h}^{-1}$ or $\left.6.6 \mathrm{BL} \mathrm{h}^{-1}\right)$. When averaging these together, $\tilde{a}=35.5 \pm 29.3 \mathrm{~cm} \mathrm{~h}^{-1}(7.0 \pm 5.7 \mathrm{BL}$ $\left.\mathrm{h}^{-1}\right)$, giving a mean swept area rate $(\tilde{a} \times$ body width $\times$ distance $/ t$ ) of $81.6 \mathrm{~cm}^{-2} \mathrm{~h}^{-1}$. The speed and direction of movement was neither constant nor unidirectional (Fig. 2), reflecting a 'run and mill' movement pattern (Kaufmann and Smith 1997), i.e. relatively large distances are achieved with minimal changes in speed and direction (routine locomotion) and are interspersed with bouts of localised, closely spaced turns that allow sediment processing and feeding (milling activity, sensu Smith et al. 1993; Fig. 2). Closer examination of our images suggests that feeding does not take place during routine locomotion (all feeding tentacles protrude forward clear of the sediment-water interface), rather feeding tentacles only contact the sediment-water interface during milling activity (Fig. 3). This demarcation of behaviour alters the locomotion ability of the organism and leads to temporally distinct activity periods. For example, following its first appearance (Period A), E. atakama exhibited a locomotion speed of $59.3 \mathrm{~cm} \mathrm{~h}^{-1}$ for $26 \mathrm{~min}\left(11.6 \mathrm{BL} \mathrm{h}^{-1}\right)$ before it began a bout of feeding (or milling) activity for $55 \mathrm{~min}$ in a localised area, characterised by irregular but short-distance movements at $17.4 \mathrm{~cm} \mathrm{~h}^{-1}\left(3.4 \mathrm{BL} \mathrm{h}^{-1}\right)$. On the cessation of any obvious feeding activity, locomotion speed increased to $61.7 \mathrm{~cm} \mathrm{~h}^{-1}\left(12.1 \mathrm{BL} \mathrm{h}^{-1}\right)$ for $53 \mathrm{~min}$ before feeding started again at a speed of $15.4 \mathrm{~cm} \mathrm{~h}^{-1}\left(3.0 \mathrm{BL} \mathrm{h}^{-1}\right)$ for $6 \mathrm{~min}$. Similar observations were also observed in the second period (Period B), where E. atakama fed for the first $49 \mathrm{~min}$ at a speed of $23.0 \mathrm{~cm} \mathrm{~h}^{-1}\left(4.5 \mathrm{BL} \mathrm{h}^{-1}\right)$ before relocating at a speed of $43.6 \mathrm{~cm} \mathrm{~h}^{-1}\left(8.5 \mathrm{BL} \mathrm{h}^{-1}\right)$ for $27 \mathrm{~min}$ until exiting the field of view. In the third appearance (Period C), E. atakama fed for the majority of time (152 min) with two small periods of routine movements ( 31 and $20 \mathrm{~min}$ ). The locomotion speed during bouts of relocation was $54.0 \mathrm{~cm} \mathrm{~h}^{-1}\left(10.6 \mathrm{BL} \mathrm{h}^{-1}\right)$, but during feeding, reduced to $27.1 \mathrm{~cm} \mathrm{~h}^{-1}\left(5.3 \mathrm{BL} \mathrm{h}^{-1}\right)$. In total,
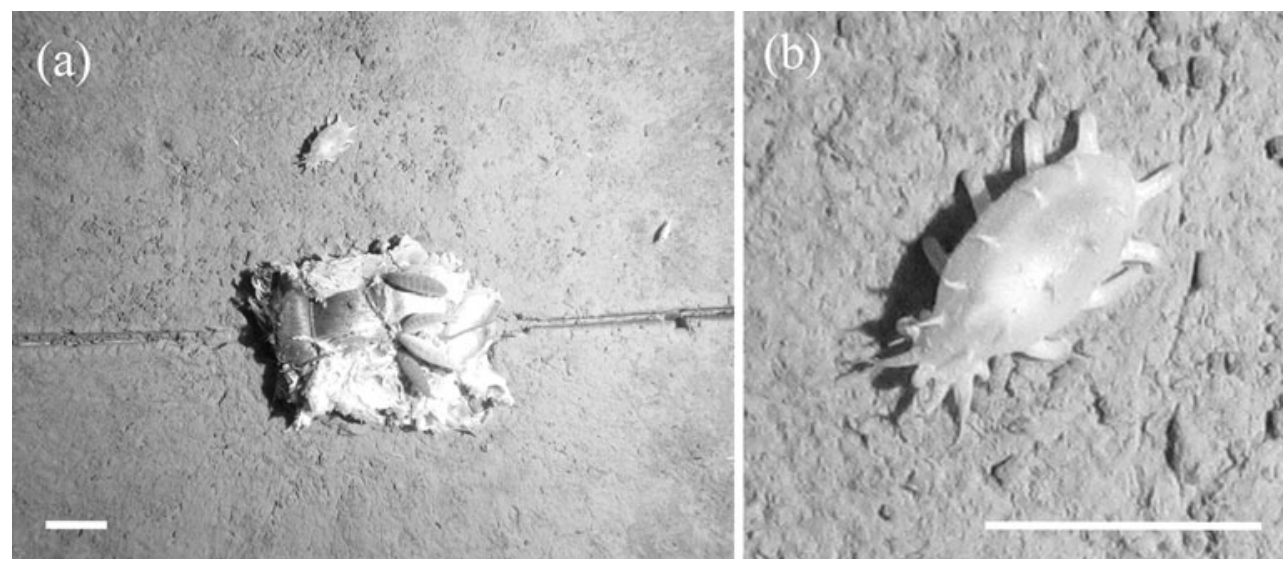

Fig. 1 a Full field of view image from 8,075 $\mathrm{m}$ showing the tuna bait parcel in the centre with four scavenging amphipods (Eurythenes gryllus) beginning to feed. In the centre, middle is the holothurian Elpidia atakama. b Close-up of E. atakama. Scales bars $=5 \mathrm{~cm}$ 
Fig. 2 Absolute speed $\left(\mathrm{cm} \min ^{-1}\right)$ over time and the $\mathrm{X}-\mathrm{Y}$ track for the three appearances of E. atakama $(\mathbf{a}, \mathbf{b}, \mathbf{c})$. Periods of feeding (milling) activity are shaded. Trend lines are 10 min moving averages. In the right hand panels, $S$ marks the start position and $E$ the end position
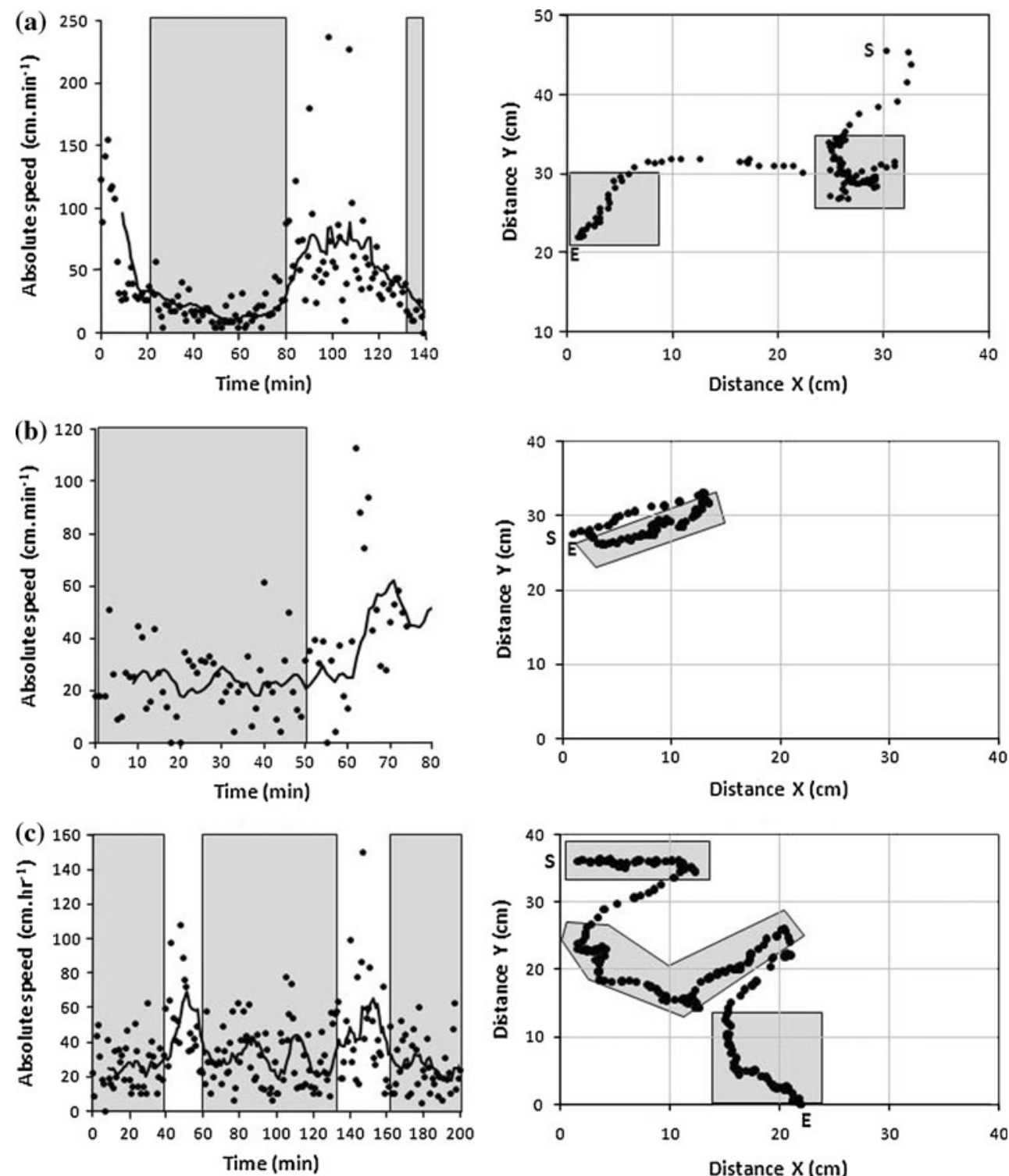

E. atakama spent 150 min relocating and 267 min feeding (a ratio of 1:1.8). By distinguishing between routine locomotion and feeding locomotion, mean locomotive speeds were $55.7 \pm 36.7 \mathrm{~cm} \mathrm{~h}^{-1}\left(10.9 \pm 7.2 \mathrm{BL} \mathrm{h}^{-1}\right)$ and $24.3 \pm 14.8 \mathrm{~cm} \mathrm{~h}^{-1}\left(4.77 \pm 2.9 \mathrm{~cm} \mathrm{~h}^{-1}\right)$, respectively.

It is important to place the current observations within the context of other known observations of holothurian behaviour (Table 1). Whilst it is clear that the rate of locomotion in E. atakama is faster than many other species, these differences relate only poorly to increasing depth (Fig. 4a) or to body size (Fig. 4b). An alternative explanation may be that the rate of locomotion relates to the quality and reliability of food supply, although this hypothesis has not been tested explicitly and we acknowledge that comparisons between studies are difficult to make given the lack of available data and differences in methodology (Fig. 5). Re-analysis of our own data showed that increasing the time-lapse interval over the observation period results in a rapid (logarithmic) increase in error, resulting in $>55 \%$ estimate error when images are taken at 60-min intervals (decreases from 7.0 $\pm 5.7 \mathrm{BL} \mathrm{h}^{-1}$ to $3.2 \pm 0.9 \mathrm{BL} \mathrm{h}^{-1}$; Fig. 5a), relative to the highest resolution of observations (1 min). Data using 60-min intervals from Kaufmann and Smith (1997) and Smith et al. (1993) and 1-min intervals from (Smith et al. 1997) are in good agreement with our predictions (Fig. 5b). Furthermore, the measurements of the rate of movement of Elpidia minutissima (Smith et al. 1993; Kaufmann and Smith 1997) are almost equal to those of E. atakama based on a theoretical 60-min interval. 

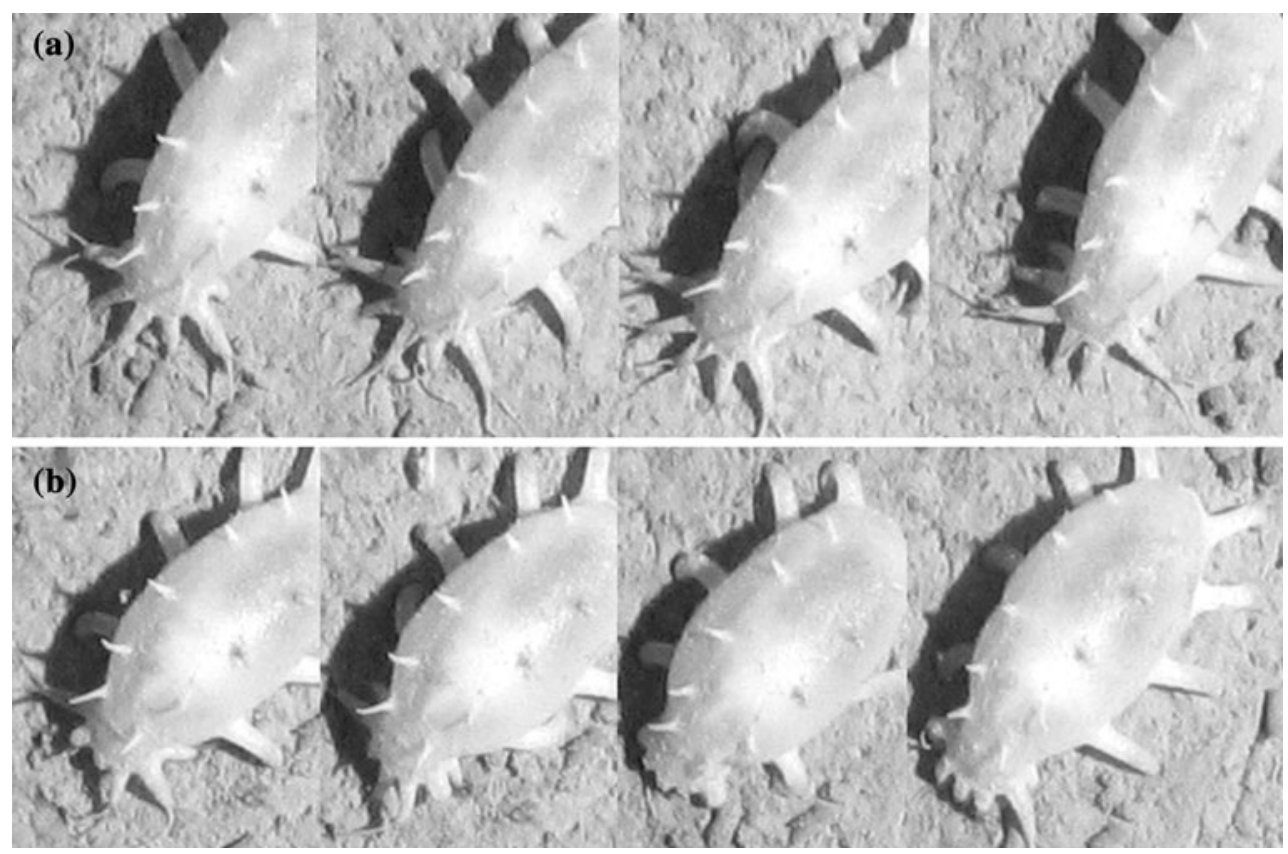

Fig. 3 The a locomotion and $\mathbf{b}$ feeding behaviour of E. atakama. Feeding tentacles are a positioned to the anterior (the bottom of each image) and raised above the sediment-water interface during locomotion and $\mathbf{b}$ lowered to intersect the sediment-water interface during bout of feeding. Frames were selected at random from successive bouts of locomotion and feeding

Table 1 Summary of measured body length (BL), absolute (a) and size-specific locomotion speeds for holothurians at a range of depths

\begin{tabular}{llllll}
\hline Species & Depth $(\mathrm{m})$ & $\mathrm{BL}(\mathrm{cm})$ & $\tilde{a}\left(\mathrm{~cm} \mathrm{~h}^{-1}\right)$ & $\begin{array}{l}\text { Size-specific } \\
\text { speed }\left(\mathrm{BL} \mathrm{h}^{-1}\right)\end{array}$ & Source \\
\hline Laetmogone violacea & 1,000 & 14.0 & 102.6 & 7.3 & Smith et al. (1997) \\
Benthogone rosea & $2,012-2,019$ & 17.0 & 89.0 & 5.0 & Billett (1991) \\
Staurocucmuis abyssorum & 4,100 & 12.9 & 12.8 & 1.0 & Kaufmann and Smith (1997) \\
Staurocucumis abyssorum & 4,100 & 9.7 & 17.8 & 1.8 & Smith et al. (1993) \\
Elpidia minutissima & 4,100 & 4.4 & 11.9 & 2.7 & Kaufmann and Smith (1997) \\
Elpidia minutissima & 4,100 & 4.1 & 14.8 & 3.6 & Smith et al. (1993) \\
Peniagone vitrea & 4,100 & 8.6 & 10.1 & 1.2 & Kaufmann and Smith (1997) \\
Peniagone vitrea & 4,100 & 7.3 & 8.1 & 1.1 & Smith et al. (1993) \\
Scotoplanes globosa & 4,100 & 9.5 & 16.3 & 1.7 & Kaufmann and Smith (1997) \\
Synallactes profundi & 4,100 & 17.4 & 12.7 & 0.7 & Kaufmann and Smith (1997) \\
Oneirophanta mutabilis & 4,100 & 15.3 & 64.6 & 4.2 & Kaufmann and Smith (1997) \\
Oneirophanta mutabilis & 4,100 & 14.3 & 84.8 & 5.9 & Smith et al. (1993) \\
Oneirophanta mutabilis & 4,844 & 16.2 & 128.9 & 8.0 & Smith et al. (1997) \\
Elpidia atakama & 8,074 & 5.1 & 37.3 & 7.3 & Present study \\
\hline
\end{tabular}

\section{Discussion}

We have documented the feeding and locomotion behaviour of a hadal holothurian and shown that the behaviour is not exceptional; the run and mill pattern of Elpidia atakama exemplifies patterns of behaviour of functionally analogous abyssal species in the NE Pacific, including Elpidia minutisima, Staurocucumis abyssorum, Synallactes profundi, Peniagone vitrea and Scotoplanes globosa
(Smith et al. 1993; Kaufmann and Smith 1997), and locomotion and feeding rates are comparable to holothurians found at shallower depths. However, our findings provide compelling evidence that E. atakama is a functionally important species that is likely to change its behaviour in response to localised resource heterogeneity (Godbold et al. 2009, 2011) and the repackaging of organic matter (OM; Bett et al. 2001). Also, movement over the sediment surface associated with relocation constitutes 
Fig. 4 Summary of observations of size-specific locomotion speed $\left(\mathrm{BL} \mathrm{h}^{-1}\right)$ for a water column depth and b body size of individual holothurians. Open circles represent measurements for E. atakama in the present study, whilst closed circles represent the data listed in Table 1
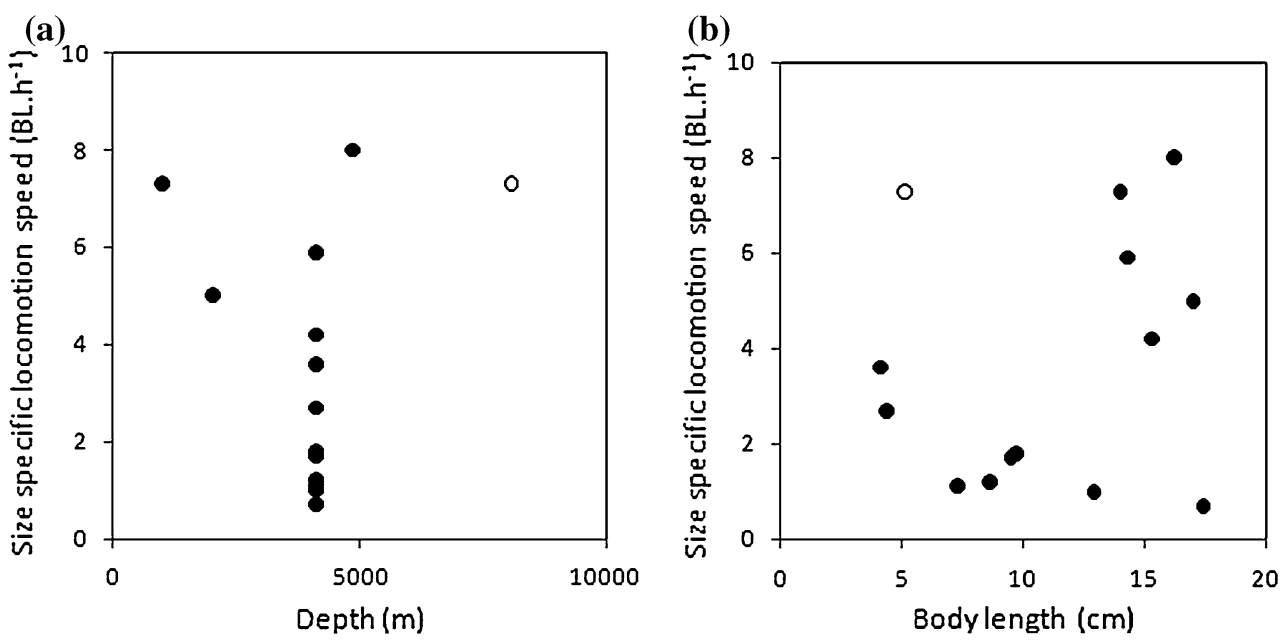

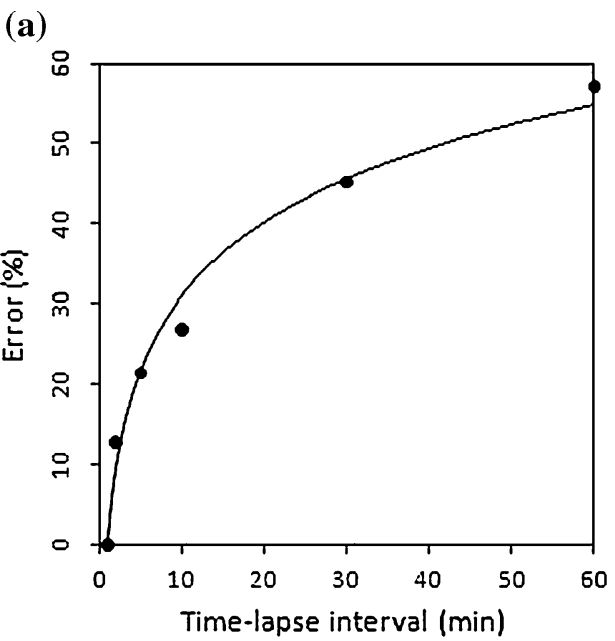

Fig. 5 The effect of increasing the elapsed time between successive time-lapse images on mean locomotion speeds for the holothurians listed in Table 1. In a, the degree of estimation error increases rapidly as time-lapse intervals are extended (recalculated from present study data). In b, data are shown for E. atakama at 1-, 2-, 5-, 10-, 30-, and

bioturbation which is qualitatively distinct from bioturbation associated with feeding activity (Bulling et al. 2008), giving credence to the view that epifaunal species can have a substantial effect on the properties of the sediment profile (Solan et al. 2004). It is, however, difficult to assess the ecological contribution of E. atakama in the absence of information on the spatial extent and temporal persistence of this species. There are no abundance estimates for E. atakama (or any other holothurian) in the Peru-Chile Trench. However, a review of all-known hadal records up to 1989 found that the density of both E. uschakovi in the New Hebrides trench and Elpidia sp. from the Palau trench was 0.1 ind. $\mathrm{m}^{-2}\left(=1,000\right.$ ind. ha $\left.{ }^{-1}\right)$, whilst the density of E. solomonensis from the New Britain and Bougainville Trenches ranged from 0.03 to 0.1 and 0.01 ind. $\mathrm{m}^{-2}$, respectively (300-1,000 ind. $\mathrm{ha}^{-1}$ and 100 ind. ha ${ }^{-1}$;

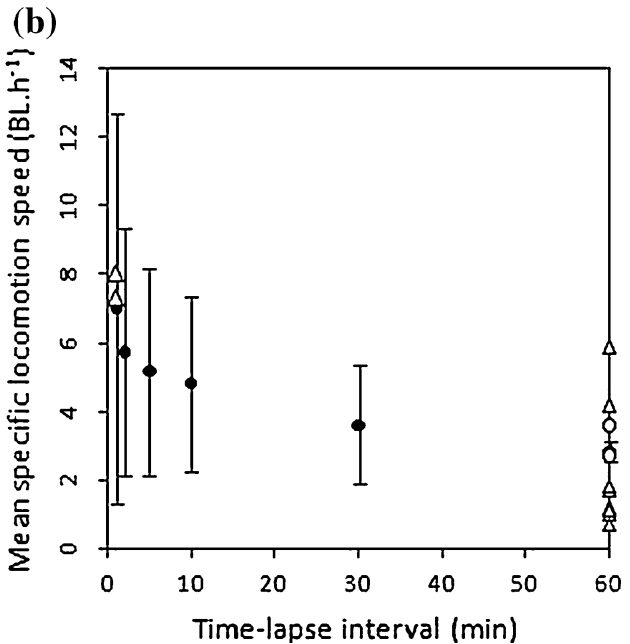

60-min time-lapse intervals (recalculated from present study data) alongside previously published data (triangles) for the abyssal species listed in Table 1. Estimates for E. minutissima are denoted by grey circles

Belyaev 1989). In general, however, the density of the Elpidiidae family (Elpidia glacialis ushakovi, E. glacialis solomonensis, Elipida sp., Peniagone purpurea, P. azorica and Scotoplanes globosa) at hadal depths can range from 0.5 to 10 ind. $\mathrm{m}^{-2}\left(5,000-100,000\right.$ ind. $\mathrm{ha}^{-1}$ ) (Lemche et al. 1976). More recent reports from the Orkney trench (Vinogradova et al. 1993; Gebruk 1993) suggest for E. decapoda, a density of 15 ind. $\mathrm{m}^{-2}\left(150,000\right.$ ind. ha $\left.{ }^{-1}\right)$ at $6,160 \mathrm{~m}$ and 30 ind. $\mathrm{m}^{-2}\left(300,000\right.$ ind. ha $\left.{ }^{-1}\right)$ at 5,580 m. These estimates are considerably higher than those reported for the abyssal plains; most reports indicate 15.5-193.3 ind. $\mathrm{ha}^{-1}$, although there are some exceptions, e.g. 370.8 ind. ha ${ }^{-1}$, E. minutissima in the NE Pacific (Kaufmann and Smith 1997) and in the NE Atlantic, 8.77-337.92 ind. ha ${ }^{-1}$ for Amperima rosea, and 43,949 ind. ha ${ }^{-1}$ for Elpidia echinata, although there are instances of mass occurrences 
of Kolga hyaline at 501,701 ind. $\mathrm{ha}^{-1}$ (Billett and Hansen 1982; Billett 1991; Billett et al. 2001). Nevertheless, using the calculated sweep area and observations of feeding activity obtained here, we estimate that a single individual of $E$. atakama may process $1 \mathrm{~m}^{2}$ of surficial sediment every 5.1 days, or a population of 123 individuals will turnover $1 \mathrm{~m}^{2}$ of surficial sediment every hour.

When considered together, the available estimates of holothurian density provide anecdotal evidence that holothurians are found in greatest abundance at hadal depths, rather than at adjacent abyssal areas. Mass abundances of hadal holothurians are thought to occur at the trench axis where elevated levels of organic material are likely to accumulate (Otosaka and Noriki 2000; Danovaro et al. 2003; Jamieson et al. 2010; Itoh et al. 2011). This appears to reflect a general relationship with topography (Rowe 1971) as concentrations of elpidiids are a common feature of underwater canyons and other depressions which are known to contain elevated levels of organic matter and deposit feeding benthic biomass (De Leo et al. 2010). It has been shown that density of benthic assemblages in trenches tends to be related positively to productivity in surface waters: highest densities in trenches that occur at high latitudes and/or close to continents (Belyaev 1989). Whilst it is tempting to speculate that the behaviour we have observed here is a response to the spatio-temporal variability in the extent and intensity of food supply (Ruhl 2007; Smith et al. 2009), the study region is eutrophic, and food resources are plentiful, albeit complicated by interannual phenomena of the region, including the El Nino Southern Oscillation and the development of oxygen minimum zones (Thiel et al. 2007). Furthermore, interannual and seasonal variation in abundances of abyssal holothurians is known to occur (Billett et al. 2001, 2010; Ruhl 2007; Smith et al. 2009) and will also be likely at hadal depths. Under these circumstances, it is unlikely that competition for resources will lead to behavioural differences in feeding strategy (Godbold et al. 2009). In the present study, E. atakama spent $150 \mathrm{~min}$ relocating and 267 min feeding (a ratio of 1:1.8), suggesting that resource supply is indeed abundant and that the distance between patches is relatively short $(20-40 \mathrm{~min}$ travel time, or approximately 10 body length distance). This pattern of movement suggests considerable sensitivity to food concentration (McClintic et al. 2008) and implies that the dynamics and organisation of hadal communities are intimately linked to habitat structure and the distribution of resources in ways similar to those found in shallower benthic communities (Levinton and Kelaher 2004; Dyson et al. 2007; Bulling et al. 2008; Nogaro et al. 2008; Godbold et al. 2011). Thus, the cumulative response of hadal species to such small-scale variation is likely to influence species contributions to ecosystem properties at much larger scales (Godbold et al. 2011).

Whilst we have been able to describe the likely ecological role of E. atakama at hadal depths, the high-resolution time-lapse sequences also enabled us to highlight some procedural difficulties that are likely to hinder progress in understanding the structure and functioning of hadal communities (Jamieson et al. 2010). Reanalysis of our timelapse sequences at progressively lower temporal resolution suggests that the extended time-lapse intervals used in longterm observatories (Kaufmann and Smith 1997) are likely to miss the subtleties of holothurian behaviour and grossly underestimate the locomotion/feeding rates of individual species, because rest periods and alternative bouts of behaviour can occur between successive images (typically $<1 \mathrm{~h})$. This source of error makes pairwise comparisons between different studies, locations or seasons difficult and hinders generic understanding of ecological phenomena (Benton et al. 2007). If we are to fully appreciate the functional role of organisms that inhabit the deepest parts of our oceans, extended observations are now needed that appreciate the temporal and spatial scales at which speciesenvironment interactions occur and which aim to test unambiguously ecological theory.

Acknowledgments Supported by the HADEEP project (Nippon Foundation, Japan, and the Natural Environmental Research Council, UK). We thank the chief scientist Prof. Hans-Joachim Wagner (University of Tübingen, Germany) and the crew of the RV Sonne SO209. We thank Dr. Niamh Kilgallen (National Institute for Water and Atmosphere research, New Zealand) and Dr. Kota Kitazawa (Atmosphere and Ocean Research Institute, University of Tokyo, Japan) for their assistance at sea. AJJ is currently supported by the Marine Alliance for Science and Technology Scotland (MASTS).

\section{References}

Amaro T, Bianchelli S, Billett DSM, Cunha MR, Pusceddu A, Danovaro R (2010) The trophic biology of the holothurian Molpadia musculus: implications for organic matter cycling and ecosystem functioning in a deep submarine canyon. Biogeosciences 7:2419-2432

Angel MV (1982) Ocean trench conservation. International union for conservation of nature and natural resources. Environmentalist 2:1-17

Belyaev GM (1971) Deep water holothurians of the genus Elpidia. Transactions of P. P. Shirshov Inst Oceanol 92:326-367

Belyaev GM (1989) Deep-Sea Ocean trenches and their fauna. Nauka Publishing House, Moscow, p 385 (Translated to English from Russian by Scripps Institution of Oceanography, USA, 2004)

Benton TG, Solan M, Travis J, Sait SM (2007) Microcosm experiments can inform global ecological problems. Trends Ecol Evol 22:516-521

Bett BJ, Rice AL (1993) The feeding behaviour of an abyssal echiuran revealed by in situ time-lapse photography. Deep-Sea Res I 40:1767-1779

Bett BJ, Malzone MG, Narayanaswamy BE, Wigham BD (2001) Temporal variability in phytodetritus and megabenthic activity at 
the seabed in the deep Northeast Atlantic. Prog Oceanogr 50: 349-368

Billett DSM (1991) Deep-sea holothurians. Oceanogr Mar Biol 29:259-317

Billett DSM, Hansen B (1982) Abyssal aggregations of Kolga hyalina Danielssen and Koren (Echinodermata: Holothurioidea) in the northeast Atlantic Ocean: a preliminary report. Deep Sea Res A 29(7):799-818

Billett DSM, Bett BJ, Rice AL, Thurston MH, Galéron J, Sibuet M, Wolff GA (2001) Long-term change in the megabenthos of the Porcupine Abyssal Plain (NE Atlantic). Prog Oceanogr 50: 325-348

Billett DSM, Bett B, Reid WDK, Boorman B, Priede IG (2010) Longterm change in the abyssal NE Atlantic: the 'Amperima Event' revisited. Deep Sea Res II 57(15):1406-1417

Bulling MT, Solan M, Dyson KE, Hernandez-Millian G, Lastra P, Pierce GJ, Raffaelli DG, Paterson DM, White PCL (2008) Species effects on ecosystem processes are modified by faunal responses to habitat quality. Oecologia 158:511-520

Danovaro R, Della Croce N, Dell'Anno A, Pusceddu A (2003) A depocenter of organic matter at 7,800 m depth in SE Pacific Ocean. Deep-Sea Res I 50:1411-1420

De Leo FC, Smith CR, Rowden AA, Bowden DA, Clarke MR (2010) Submarine canyons: hotspots of benthic biomass and productivity in the deep sea. P Roy Soc Lond B Bio 277:2783-2792

Dyson KE, Bulling MT, Solan M, Hernandez-Milian G, Raffaelli DG, White PC, Paterson DM (2007) Influence of macrofaunal assemblages and environmental heterogeneity on microphytobenthic production in experimental systems. P Roy Soc Lond B 274:2547-2554

Echevin V, Aumont O, Ledesma J, Flores G (2008) The seasonal cycle of surface chlorophyll in the Peruvian upwelling system: a modelling study. Prog Oceanogr 79:167-176

Fletcher B, Bowen A, Yoerger DR, Whitcomb LL (2010) Journey to the challenger deep: 50 years later with the Nereus hybrid remotely operated vehicle. Mar Tech Soc J 43:65-76

Fossing H, Gallardo VA, Jørgensen BB, Hüttel M, Nielsen LP, Schulz H, Candfield D, Forster S, Glud RN, Gundersen JK, Ramsing NB, Teske A, Thamdup B, Ulloa O (1995) Concentration and transport of nitrate by mat-forming sulphur bacterium Thioploca. Nature 374:713-715

Gebruk AV (1993) New records of elasipodid holothurians in the Atlantic sector of Antarctic and Subantarctic. Transactions of P.P. Shirshov Inst Oceanol 127:228-244

Godbold JA, Rosenberg R, Solan M (2009) Species-specific traits rather than resource partitioning mediate diversity effects on resource use. PLoS ONE 4:e7423. doi:10.1371/journal.pone. 0007423

Godbold JA, Bulling MT, Solan M (2011) Habitat structure mediates biodiversity effects on ecosystem properties. P Roy Soc Lond B doi:10.1098/rspb.2010.2414

Hansen B (1957) Holothurioidea from depths exceeding 6,000 m. Galathea Rep 2:33-54

Hansen B (1975) Systematics and biology of the deep-sea holothurians. Galathea Rep 13:1-262

Hauksson E (1979) Feeding biology of Stichopus tremulus, a depositfeeding holothurian. Sarsia 64:155-160

Hiratsuka Y, Uehara T (2007) Feeding rates and absorption efficiencies of four species of sea urchins (genus Echinometra) fed a prepared diet. Comp Biochem Phys A 148:223-229

Hudson IR, Wigham BD, Solan M, Rosenburg R (2005) Feeding behaviour of deep-sea dwelling holothurians: Inferences from a laboratory investigation of shallow fjordic species. J Marine Syst 57:201-218

Itoh M, Kawamura K, Kitahashi T, Kojima S, Katagiri H, Shimanaga M (2011) Bathymetric patterns of meiofaunal abundance and biomass associated with the Kuril and Ryukyu trenches, western North Pacific Ocean. Deep-Sea Res I 58:86-97

Jamieson AJ, Solan M, Fujii T (2009a) Imaging deep-sea life beyond the abyssal zone. Sea Technol 50:41-46

Jamieson AJ, Fujii T, Solan M, Priede IG (2009b) HADEEP: freefalling landers to the deepest places on Earth. Mar Tech Soc J 43:151-159

Jamieson AJ, Fujii T, Mayor DJ, Solan M, Priede IG (2010) Hadal Trenches: the ecology of the deepest places on Earth. Trends Ecol Evol 25:190-197

Kaufmann RS, Smith KL (1997) Activity patterns of mobile epibenthic megafauna at an abyssal site in the eastern North Pacific: results from a 17-month time-lapse photographic study. Deep-Sea Res I 44:559-579

Lemche H, Hansen B, Madsen FJ, Tendal OS, Wolff T (1976) Hadal life as analysed from photographs. Vidensk Meddr Dansk Naturh Foren 139:263-336

Levinton J, Kelaher B (2004) Opposing organising forces of depositfeeding marine communities. J Exp Mar Biol Ecol 300: 65-82

Longhurst A, Sathyendranath S, Patt T, Caverhill C (1995) An estimate of global primary production in the ocean from satellite radiometer data. J Plankton Res 17:1245-1271

Lopez GR, Levinton JS (1987) Ecology of deposit-feeding animals in marine sediments. Q Rev Biol 62:235-260

McClintic MA, DeMaster DJ, Thomas CJ, Smith CR (2008) Testing the FOODBANCS hypothesis: seasonal variations in nearbottom particle flux, bioturbation intensity, and deposit feeding based on Th-234 measurements. Deep-Sea Res II 55:2425-2437

Miller RJ, Smith CR, DeMaster DJ, Fornes WL (2000) Feeding selectivity and rapid particle processing by deep-sea megafaunal deposit feeders: A ${ }^{234}$ Th tracer approach. J Mar Res 58:653-673

Nogaro G, Charles F, de Mendonça JB Jr, Mermillod-Blondin F, Stora G, François-Carcaillet F (2008) Food supply impacts sediment reworking by Nereis diversicolor. Hydrobiologia 598:403-408

Ohta S (1983) Photographic census of large-sized benthic organisms in the bathyal zone of Suruga Bay, Central Japan, volume 15. Bulletin of the Ocean Research Institute, University of Tokyo, p 244

Otosaka S, Noriki S (2000) REEs and Mn/Al ratio of settling particles: horizontal transport of particulate material in the northern Japan Trench. Mar Chem 72:329-342

Perrone FM, Dell'Anno A, Danovaro R, Della Croce N, Thurston MH (2002) Population biology of Hirondellea sp nov (Amphipoda : Gammaridea : Lysianassoidea) from the Atacama Trench (southeast Pacific Ocean). J Mar Biol Ass UK 82:419-425

Rice AL, Aldred RG, Darlington E, Wild RA (1982) The quantitative estimation of the deep-sea megabenthos a new approach to an old problem. Oceanol Acta 5:63-72

Roberts D, Gebruk A, Levin V, Manship BAD (2000) Feeding and digestive strategies in deposit-feeding holothurians. Oceanogr Mar Biol 38:257-310

Rowe GT (1971) Observations on bottom currents and epibenthic populations in Hatteras Submarine Canyon. Deep-Sea Res 18:559-581

Ruhl HA (2007) Abundance and size distribution dynamics of abyssal epibenthic megafauna in the northeast Pacific. Ecology 88: $1250-1262$

Saunders PM (1981) Practical conversion of pressure to depth. J Phys Oceanogr 11:573-574

Sibuet M (1985) Quantitative distribution of echinoderms (Holothuroidea. Asteroidea. Ophiuroidea. Echinoidea) in relation to organic matter in the sediment, in deep-sea basins of the Atlantic Ocean. In: Keegan BF, O'Connor BF, BDS (eds) Echinodermata Balkema, Rotterdam, pp 99-103 
Sibuet M, Lawrence JM (1981) Organic content and biomass of abyssal holothuroids (Echinodermata) from the Bay of Biscay. Mar Biol 65:143-147

Smith KL, Kaufmann RS, Wakefield WW (1993) Mobile megafaunal activity monitored with a time-lapse camera in the abyssal North Pacific. Deep-Sea Res I 40:2307-2324

Smith A, Matthiopoulos J, Priede IG (1997) Areal coverage of the ocean floor by the deep-sea elasipodid holothurian Oneirophanta mutabilis: estimates using systematic, random and directional search strategy simulations. Deep-Sea Res I 44:477-486

Smith KL, Ruhl HA, Bett BJ, Billett DSM, Lampitt RS, Kaufmann RS (2009) Climate and deep-sea communities. Proc Nat Acad Sci USA 46:19211-19218

Solan M, Wigham BD, Hudson IR, Coulon CH, Kennedy R, Norling $\mathrm{K}$, Nilsson H, Rosenberg R (2004) In situ quantification of infaunal bioturbation using fluorescent sediment profile imaging (f-SPI), luminophore tracers and model simulation. Mar Ecol Prog Ser 271:1-12

Teal LR, Bulling MT, Parker ER, Solan M (2008) Global patterns of bioturbation intensity and the mixed depth of marine soft sediments. Aquat Biol 2:207-218

Thiel M, Macaya EC, Acuna E, Arntz WE, Bastias H, Brokordt K, Camus PA, Castilla JC, Castro LR, Cortes M, Dumont CP, Escribano R, Fernandez M, Gajardo JA, Gaymer CF, Gomez I, Gonzalez AE, Gonzalez HE, Haye PA, Illanes JE, Iriarte JL,
Lancellotti DA, Luna-Jorquerai G, Luxoroi C, Manriquez PH, Marin V, Munoz P, Navarrete SA, Perez E, Poulin E, Sellanes J, Sepulveda HH, Stotz W, Tala F, Thomas A, Vargas CA, Vasquez JA, Vega JMA (2007) The Humboldt Current system of northern and central Chile. Oceanogr Mar Biol Ann Rev 45: 195-344

Thurston MH, Petrillo M, Della Croce N (2002) Population structure of the necrophagous amphipod Eurythenes gryllus (Amphipoda: Gammaridea) from the Atacama Trench (south-east Pacific Ocean). J Mar Biol Ass UK 82:205-211

Uthicke S (1999) Sediment bioturbation and impact of feeding activity of Holothuria (Halodeima) atra and Stichopus chloronotus, two sediment feeding holothurians, at Lizard Island, Great Barrier Reef. Bull Mar Sci 64:129-141

Uthicke S, Karez R (1999) Sediment patch selectivity in tropical sea cucumbers (Holothurioidea: Aspidochirtida) analysed with multiple choice experiments. J Exp Mar Biol Ecol 236:69-87

Vinogradova, NG, Gebruk, AV, Romanov, VN (1993) Some new data on the ultraabyssal fauna of the Orkney Trench. In: Klekowski, RZ, Opalinski, KW (eds) The Second Polish-Soviet Antarctic Symposium, Arctowski' 91. Institute of Ecology, pp 213-221

Yang HS, Nozaki Y, Sakai H, Nagaya Y, Nakamura K (1986) Natural and man-made radionuclide distributions in northwest Pacific deep-sea sediments: rates of sedimentation, bioturbation and 226Ra migration. Geochem J 20:29-40 